\title{
Et fantastisk studium
}

Jeg ønsker å rose det varme læringsmiljøet på sykehuset, der dørene alltid er åpne for ekstra praksis og ferdighetstrening. Medisinstudiet er slik at man selv kan velge hvordan man vil legge løpet. Min måte er å delta på mye utenom oppsatt uketjeneste. Det gir meg mestringsfølelse i hverdagen.

Jeg er nå ferdig med fjerde året på medisinstudiet $\mathrm{i}$ Trondheim, og årene har rast av gårde. Det sies at tiden flyr når man har det gøy, og det kan stemme. For mye gøy har jeg hatt det i ulike læringssituasjoner på dette studiet. Læringskurven har vært bratt, og pensummassen tung, men hver uke opplever jeg også en søt følelse av mestring, enten det er fordi jeg har stiftet en buk sammen for første gang eller fordi jeg har fått frem en helt ny opplysning ved å spørre en pasient «Hvordan har ditt syn på livet forandret seg etter at du ble syk?».

Selv om et slikt gyllent øyeblikk ikke betyr at man kan alt eller føler at man er virkelig god på noe, gir det en opplevelse av at man er i utvikling, på vei et sted. Jeg føler at medisinstudiet legger til rette for slike opplevelser, hvis man benytter seg av de mulighetene som finnes for læring.

\section{Resonnement læres}

Så klart selvfølelsen kan gå litt opp og ned i den kliniske hverdagen. Jeg har opplevd å sitte som eneste student på morgenmøtet og blitt servert et skikkelig saftig medisinsk mysterium, fremlagt som den største selvfølgelighet. Og når jeg ærlig har sagt at jeg ikke har peiling på hva det er snakk om, er det blitt humret litt muntert. Men jeg synes det er gøy å få bryne meg. Medisinstudiet gir oss utfordringer, og det liker jeg. Jeg føler ikke at det utfordrer selvtilliten og selvrespekten min, jeg synes heller det signaliserer at lærerne har tro på oss og hva vi kan. Vi har hatt tøffe, direkte utspørringer sene ettermiddager på uketjeneste - men for meg gir det veldig mye læring, uavhengig av om jeg svarer riktig eller feil.

Noe av det beste med studiet er at vi lærer oss å resonnere. Selv om man ikke vet akkurat hvilken absurd sjelden medisinsk tilstand det er snakk om når man blir spurt, kan man ut fra det man vet om andre sykdommer legge frem et resonnement. $\mathrm{Og}$

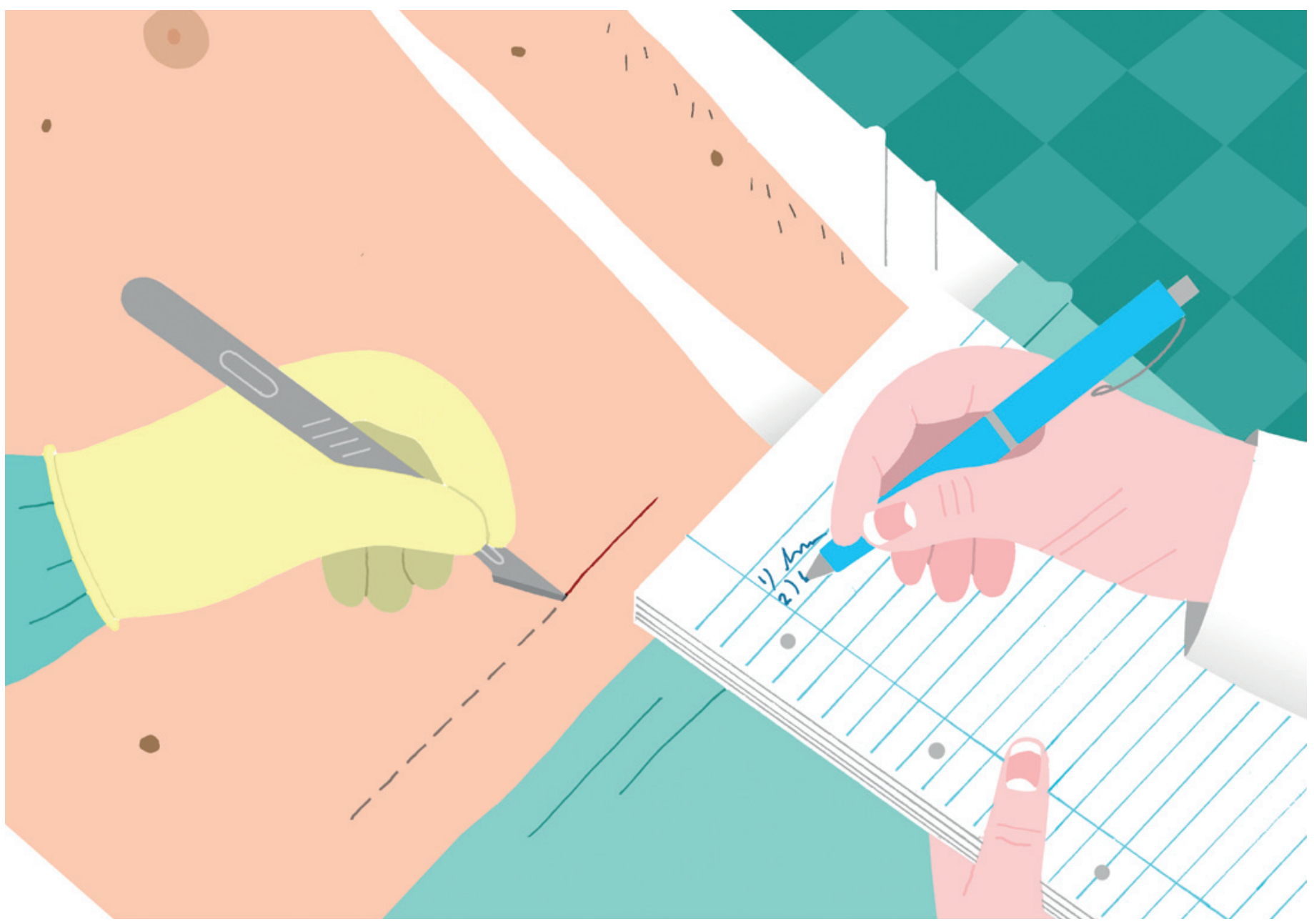


nesten uansett hvor latterlig feil det jeg har resonnert meg frem til er, har jeg opplevd at det er blitt møtt med anerkjennelse fra overleger og professorer - fordi jeg har prøvd. Og jeg tror det er det man må gjøre tørre å prøve seg.

\section{Engasjerte lærere}

Jeg opplever at mange av legene vi møter i uketjenesten er dypt engasjert i å lære bort til oss studenter. Til tross for det ekstreme arbeidspresset leger i kombinerte stillinger har, vet mange å gjøre det beste ut av det de har til rådighet. Jeg vil rose det stimulerende kliniske læringsmiljøet på sykehuset. Jeg har vært like innpåsliten som en klegg $i$ akuttmottaket, ringt ned vakthavende leger på mobil og vakttelefon og møtt på poliklinikken utenom undervisningsdag. Jeg har gått på vaktrommet til radiologene og bedt om å få tolke røntgen thorax med dem, spurt tilfeldige kirurger om å få ta innkomstjournal på pasienter med akutt abdomen og møtt uanmeldt på sengeposten ved nevrologisk avdeling og spurt om de har pasienter med funn.

Nesten uten unntak er jeg blitt kjempepositivt mottatt, selv om legene har vært svette av å ha løpt mellom operasjonsstue og traumemottak på slutten av en tolvtimers vakt. Når jeg ringer vakthavende og sier «Hei, kan jeg få være med på det som skjer?», opplever jeg at mottaker av sam- talen ser på det som en selvfølge. Jeg har til og med opplevd å komme på ettermiddagen og møte leger som legger opp et helt eget opplegg - bare til meg: «Intervju og undersøk denne pasienten, tenk grundig over hva du tror er diagnosen og kom til kontoret mitt etterpå.» Aldri om jeg glemmer kronisk inflammatorisk demyeliniserende polyradikulonevropati, og den halvtimen med privatundervisning jeg fikk etterpå.

\section{Døgnåpent sykehus}

Som student føler jeg at vi er velkomne i hverdagen på sykehuset, og vi behandles som likeverdige. Leger i spesialisering og turnusleger spiller på lag med oss og tar oss med på operasjoner, undersøkelser og prosedyrer. Ofte har jeg også opplevd at overlegene er glimrende kliniske diskusjonspartnere, hvis man når tak $\mathrm{i}$ dem ved å overrumple i et uventet øyeblikk. Mange klager over for lite praksis på medisinstudiet. Men på sykehuset er det pasienter 24 timer i døgnet. Vi har fantastiske muligheter ved å delta $\mathrm{i}$ vaktarbeid og annen klinisk virksomhet utenom den opplagte undervisningen. Da kan vi bli kjent med legene og få mulighet til å få prøve oss.

Læringsopplegget på studiet passer nok forskjellig til ulike studenters vaner og foretrukket læringsmåte. Jeg er utrolig fornøyd med den innsatsen som legges ned for at vi skal få lære kliniske ferdigheter, både av erfarne lærere og andre uten tilknytning til universitetet. Jeg er utrolig takknemlig for alle leger i spesialisering som stiller opp som uforberedte lærere $i$ en travel vaktsituasjon. Det betyr veldig mye for oss studenter som synes det å slenge seg spontant med på en vakt er det som gir oss det virkelige læringsutbyttet. Denne måten å lære på, å utnytte møter med pasientene som til enhver tid befinner seg på sykehuset, kan virkelig anbefales.

\section{Johanne Marie Iversen}

johannemi@gmail.com

Medisinsk-teknisk forskningssenter

Norges teknisk-naturvitenskapelige universitet

Johanne Marie Iversen (f. 1989) er femteårsstudent på medisinstudiet i Trondheim. Hun går på forskerlinjen i medisin, har vært tillitsvalgt for Det medisinske fakultet siden 2009 og har deltatt på flere internasjonale konferanser om medisinsk utdanning.

Forfatter har fylt ut ICMJE-skjemaet og oppgir ingen interessekonflikter

Mottatt 16.4. 2012, første revisjon innsendt 27.5. 2012, godkjent 21.6. 2012. Medisinsk redaktør Anne Kveim Lie. 